\title{
Error Analysis on English Translation from Indonesian on Public Facilities in Semarang City
}

\author{
${ }^{1}$ Ayu Ida Savitri \\ ${ }^{1}$ Linguistics Department, Faculty of Humanities, \\ Diponegoro University, Semarang
}

(ayuidasavitri@lecturer.undip.ac.id)

Article History: Submitted May $28^{\text {th }}, 2019$; Accepted June $20^{\text {th }}, 2019$; Published July $5^{\text {th }}, 2019$

\begin{abstract}
Delivering exactly and accurately the same message of a text under minor bias and without any form and meaning shifts in another language has always becoming the final-purpose of a translation process as the main objective of translation is transferring the message of a text in one language into another one by highly considering on how the readers of another language will understand and enjoy the translation while obtaining the needed information. Most of the time, the difficulties of expressing similar message in another language lays on the different interpretation due to the different culture. To deal with it, a translator must be a 'balance-bilingual' as she/he must understand well the languages involved in the translation process. Sometimes, the error in translation occurs when the structure of the first language/the source language (SL) of the translator influence the translation in second language/ target language (TL). To analyse the error, Error Analysis Theory from Richard (1974) and Types of Error in producing English from Dulay (1982) is used as it is aimed at revealing the kinds or error along with the factors influencing the error. This research is done to describe the error in public translation such as billboard, banner and decoration containing wise words around Semarang City to show the kinds of error and the factors influencing those errors along with the way the translator translate the text under Translation Theory from Catford (1965) and Nida and Taber (1969) also Translation Model from Venuti (2000) and Translation Method and Technique/ Procedure from Vinay and Darbelnet (1958). The result shows that most of the errors are in generalization that happened as a result of the influence of the first language/SL structure and writing system that is different with that of the second language/TL.
\end{abstract}

Keywords: error analysis; translation; Indonesian-English; public translation; Semarang

Abstrak. Menyampaikan pesan yang sama dalam sebuah teks secara akurat dengan sedikit bias dan tanpa menimbulkan pergeseran bentuk dan makna selalu menjadi tujuan akhir sebuah proses penerjemahan karena tujuan utama proses penerjemahan adalah menransfer pesan dalam sebuah teks dari satu bahasa ke bahasa yang lain dengan sangat memperhatikan bagaimana pembaca dari bahasa lain akan memahami teks dengan mudah dan menikmati hasil terjemahan saat menggali informasi dalam waktu yang sama. Sebagian besar kesulitan dalam mengekspresikan pesan yang serupa dalam bahasa lain adalah adanya interpretasi yang berbeda akibat adanya perbedaan budaya. Untuk mengatasinya, seorang penerjemah harus menjadi seorang bilingual yang seimbang karena ia harus memahami betul kedua bahasa yang digunakannya dalam proses penerjemahan. Seringkali kesalahan dalam penerjemahan terjadi ketika struktur bahasa pertama/bahasa sumber (Bsu) dari seorang penerjemah mempengaruhi hasil terjemahan dalam bahasa kedua/bahasa sasaran (Bsa). Untuk menganalisis kesalahan dalam terjemahan, Teori Analisis Kesalahan dari Richard (1974) dan Jenis Kesalahan dalam memroduksi Bahasa Inggris oleh Dulay (1982) digunakan untuk menunjukkan 
jenis kesalahan dan faktor yang mempengaruhi terbentuknya kesalahan tersebut. Penelitian ini dilakukan untuk mendeskripsikan kesalahan pada terjemahan di fasilitas umum seperti papan nama/iklan, spanduk dan hiasan dinding berisi kata bijak di seputar Kota Semarang untuk menunjukkan jenis kesalahan dan faktor penyebab terjadinya kesalahan tersebut serta bagaimana penerjemah menerjemahkan teks menggunakan Teori Penerjemahan dari Catford (1965) dan Nida and Taber (1969) serta Model Penerjemahan dari Venuti (2000) dan Metode beserta Teknik/Prosedur Penerjemahan dari Vinay and Darbelnet (1958). Hasil penelitian menunjukkan bahwa sebagian besar kesalahan dalam terjemahan merupakan over-generalisation yang terjadi akibat pengaruh struktur SL/Bsu dari penerjemah yang berbeda dari struktur dan tulisan dalam TL/Bsa.

Kata kunci: analisis kesalahan; penerjemahan; Bahasa Indonesia ke Bahasa Inggris; terjemahan di tempat umum; Kota Semarang

\section{INTRODUCTION}

\section{Translation}

The term 'translation' refers to the transfer of written message, while the word 'translation' means the process of transferring the message from the Source Language or SL into the Target Language or TL (Nababan, 2003:18). In the translation process, sometimes a translator find an 'untransability' phenomenon where a term or a word is difficult or cannot be translated as there is no translation found on the TL or it will have different form and meaning if it is translated that unerringly lead to misunderstanding or even conflict. One of the text that it is not easy to translate in a name of an object or a product (goods) as a translator must be able to make translate the name and also make the readers of the TL understand the name without changing the name itself. To deal with this kind of phenomenon, a translator can use a translation model from Venuti (2000) by using the original language as it is impossible to be translated. To let the reader understand the un-translated text, a translator can add more information about the un-translated text in the form of footnote and glossary.

Another problem commonly arise in a translation process is the shift on form and meaning. In a translation process, there are two kinds of adaptation called structural and semantics adaptations (Nida and Taber, 1969:105). Structural adaptation resulted in a cultural form shift, while semantics adaptation causes a meaning shift. Thus, when a cultural form shift happens, the translated text has different form in the TL with the original form in the SL although it does not change the message or the meaning of the whole text. Meanwhile, when a semantics adaptation occurs, the translated text has a slight different meaning in the TL with the original form in the SL even though it does not change the message or the meaning of the whole text. The example of structural adaptation is the translation of the phrase 'playing snow' into 'sedang bermain lumpur'. It does not mean that the translator is incorrectly translating the text. As 'snow' does not exist in the culture of the TL, the translator changes it into 'mud' which is common to see in the culture of the TL. Meanwhile, the example of semantic adaptation is the translation of the word 'Kanjeng Ratu Hemas' into 'The Queen of Yogyakarta Palace'. It does not mean that she is a queen of with a kingdom like Queen Elizabeth with the British Royal Kingdom as she only serves as the wife of 'Sultan Hamengkubhuwana $X$ ' who is in charge of Yogyakarta Palace as a king with 'Sultan' title, a lower title than the king and his kingdom in the past after Mataram Kingdom was divided into Kesultanan Yogyakarta and Kesunanan Surakarta. 
Catford (1965:73) defines shift as a change of the form and meaning of the SL which is divided into level and category shifts. The level shift happens when the text in the SL has different linguistics level with the TL and the translator must change the linguistics level to suit the TL. Meanwhile, the meaning shift occurs when the translated text in TL has different language category with the SL as it has different structure, word class, language-unit and language intra-system. The example of level/rank shift is the translation of the word 'are playing' into 'sedang bermain' which has different linguistics level as the word 'are' does not mean 'sedang' but it must be translated into 'sedang bermain' to show the present continuous/progressive tense the text in SL. Meanwhile, the example of category shift is the translation of the word 'kuwalat' into 'being impolite and get paid' which has different structure, word class, language unit and language intra-system as there are no translation of the word 'kuwalat' which means 'someone who is being impolite into someone else who are older or has a higher status and get the paid for his/her bad deed'.

To deal with this kind of phenomenon, a translator can use Vinay and Darbelnet (1985) two Methods of Translation along with its seven Techniques/Procedures of Translation. The first method is Direct Method which is used to directly translate a text resulted in 'a quotation of the original text in SL' using three Techniques/Procedures called Borrowing, Calque and Literal Translations. Borrowing Technique/Procedure makes a translator directly borrows a word from another language (beside SL and TL) as it is difficult to or cannot be translated as there is no translation found on the TL or it will have different form and meaning if it is translated that lead to misunderstanding or conflict, such as the translation of the word 'Duke of Windsor' into 'Duke dari Windsor' as there is no translation for the word 'duke' in Indonesian and it is not suitable if it is translated into 'adipati' as it has different meaning. Calque Technique/Procedure makes a translator use the structure of the SL on the translation in the TL as it is not suitable if it uses the structure of the TL, such as the translation of the word 'I got sick' into 'saya menjadi sakit' not 'saya sakit' to show that 'someone is getting sick after doing something', not 'someone is being sick'. Literal Technique/Procedure makes a translator directly translate a text word for word like the quotation of the original text in SL such as the translation of the word 'no parking' into 'jangan parkir'.

The second method is Oblique Method which is used to translate difficult term that needs a slight change of shift to suit the TL. Transposition Technique/Procedure lets a translator change the SL structure to suit the translation in the TL such as 'I broke my legs' into 'kaki saya patah' as in Indonesian culture people never says that he/she broke his/her legs. Modulation Technique/Procedure lets a translator modulate the phrase in the SL to create a good translation in the TL such as the translation of the word 'making a will' into 'berwasiat' as making a will could means officially making a document containing the will in western countries, while making a will in Indonesian culture can be simply leaving a message before someone passed away (does not always include the document containing the will). Equivalence/Reformulation Technique/Procedure lets a translator expresses a text in a different way such as the translation of the word 'kuwalat' into 'being impolite and get paid' which resulted in category shift. Adaptation Technique/Procedure lets a translator uses different culture environment such as the translation of 'playing snow in the winter' into 'bermain lumpur di musim hujan' resulted in cultural form shift. 


\section{Error Analysis}

Error Analysis is an activity to reveal errors found in writing and speaking as it is the study of errors produced by the second and foreign language learners. By applying this study, a researcher is able to reveal how second language learners produce error in his/her second language production and the reason why they produce the errors.

Richards (1974) defines types of error produced by second language learners into interference, overgeneralization and performance error. Interference is an error produced by second language learners as an influence of the first language structure. The most common type of interference is producing incorrect English verb form as in Indonesian there is no verb form change following its tense. Overgeneralization is an error produced by second language learners by applying similar pattern for different structure as they think that all structure has the same pattern. The most common type of overgeneralization is producing incorrect English third person, past tense and plural marker as in Indonesian language there are no particular form to mark them all. Performance error is an error produced by second language learners while performing the second language, such as producing error when producing long and complex sentence which is not happening due to second language learner incompetence like using the structure of the first language.

Another types of error is shown by Dulay (1982) who divides the error prodiced by second language leaners into five surface strategies taxonomy namely omission, addition, 'misformation', 'misordering', and blend. Omission is an error produced by second language learners by omitting an item that must be shown in a well-structured sentence/utterance in the second language. It is divided into fifteen: (1) Omission of-s/-es Verb Inflection like 'It *serve pie', (2) Omission of -ed1 Verb Inflection like 'It *swim yesterday', (3) Omission of -ed2 Verb Inflection like 'It *make me happy', (4) Omission of -ing Verb Inflection after Preposition like 'I have spoon for *eat the pie', (5) Omission of -ing Verb Derivation after a To Be Linking Verb like 'My passion is *swim', (6) Omission of 'to' Infinitive Marker or -ing Verb Inflection after a Predicate Verb like 'I like *swim at night', (7) Omission of 'to' Infinitive Marker after Predicative Adjective like 'I am happy * have you', (8) Omission of 'do' Auxiliary Verb in Negation like 'We * not like it', (9) Omission of Predicate Verb like 'I* in trouble now', (10) Omission of 'be' Auxiliary Verb after Modals like 'I can * pretty to', (11) Omission of 'be' Auxiliary in Passive Voice like 'I* born to be pretty', (12) Omission of Preposition like 'I see all * them', (13) Omission of Definite Article like 'Mine is * same as yours', (14) Omission of Definite Article like 'I have *good one' and (15) Omission of -s/-es Noun Inflection in Plural Form like 'I broke my two *leg.'

Addition is an error produced by second language learners by adding an item which must not be appeared in a well-structured utterance/sentence. It is divided into twelve: (1) Addition of -s/-es Verb Inflection like 'I *has a dream', (2) Addition of-ing Verb Inflection like 'She always *singing in the classroom', (3) Addition of 'to' Verb1 Infinitive Marker in Predicative Verb like 'I usually *to sing', (4) Addition of 'be' like 'I *am sing a lot', (5) Addition of -ly Adverbial Derivation Marker like 'I can do it *fastly', (6) Addition of Preposition like 'She is going *to home', (7) Addition of Definite Article 'I like to drink *the milk', (8) Addition of Indefinite Article before A Mess Noun like 'It has *a blond hair', (9) Addition of Indefinite Article before A Plural Noun like 'It has *a four wheels', (10) Addition of Indefinite article before An Adjective like 'It is *a cute', (11) Addition of -s/-es Noun Inflection in Singular Form like 'It is *cats', (12) Addition of Derivation Affixes like 'It is also *kindly'. 
Misformation is an error produced by second language learners by using the incorrect form of structure or morpheme. It is divided into ten: (1) Misformation of 'do' Auxiliary in Negation such as 'She *do not like singing', (2) Misformation of 'be' as Verb such as 'You *is my love', (3) Misformation/misselection of 'be' instead of certain Verb such as 'It *was two storeys', (4) Misformation of Adverb for Adjective such as 'She is a *beautifully girl', (5) Misformation of Adjective instead of Adverb of Manner such as 'I sing *with very *happy', (6) Misformation of Noun instead of Adjective such as 'She sings *powerful', (7) Misformation of Noun instead of Verb such as 'She always *singing the song', (8) Misformation of Subjective Pronoun for Possessive Adjective such as '*She voice is great', (9) Misformation of Objective Pronoun for Subjective Pronoun such as '*Me and you are one', (10) Misformation of Subjective Pronoun for Objective Pronoun such as 'I have not give *they money'.

Misordering is an error produced by second language learners by using incorrect placement of morpheme or group of morphemes in an utterance/sentence such as misordering Noun Phrase Word Order like 'The cat has eyes with *blue colour'.

In addition to those four types of error from Dulay (1982), James (1998) adds one type of error named Blend which also called as contamination or cross association or hybridization error that is divided into (1) Blend of 'very' with Qualitative Adjective 'much' like 'She *very like singing', (2) Blend in If Clause for Adverb of Time like '*If she is talking, everybody listen', (3) Blend in Preposition Choice like '*In home, she is not singing', (4) Blend in Conjunction Choice like 'She is pretty and rude', (5) Blend in Diction like in using False Friend in 'The bird has beautiful *fur' or using Wordy Construction in '*Everyday, in the morning, I sing', (6) Blend in Misspelling like 'The *life is off.'

Defining how second language learners produce error in their written translation is interesting as a researcher is able to list the factor causing the error to let others avoid producing the same error while translating. This research shows the errors made by Indonesian people particularly Semarang City people who are translating texts -in public facilities- into English such as billboard, banner, or decoration board containing wise words. It is done to reveals the types of errors and the factors causing the errors. This research is beneficial for further researchers who wanted to do similar research on different object and also useful for translator to avoid producing the errors.

\section{METHOD}

This descriptive-qualitative research describes the errors of English Translation from Indonesian language produced by Indonesian people -particularly Semarang City peopleas second language learners on texts located in public facilities around Semarang City as data source to show the types of the errors and what factors causing the errors. The samples were chosen using Purposive Sampling Technique (Sudaryanto, 1993) by selecting English translations containing errors from the whole English translations as the population. The data were then categorized according to the Types of Errors produced by second language learners from Dulay (1982) and James (1998) and then finally analyzed using the Error Analysis Theory from Richards (1974). The way the translators translate the texts were also analyzed based on the Translation Model from Venuti (2007) and the Translation Method and Technique/Procedure from Vinay and Darbelnet (1958) to see how the texts were translated. 


\section{RESULTS AND DISCUSSION}

\section{Result}

After the whole data were collected by selecting the translations containing errors on billboard, banner and decoration containing wise words around Semarang City, the obtained data were classified based on their way of translation which uses Venuti (2000) Translation Model or Vinay and Darbelnet (1958) Translation Methods and Techniques/Procedures to see how the texts were translated. The next step is classifying the errors produced by the translators based on Dulay (1982) and James (1998) Types of Error produced by second language learners. Finally, the errors were analyzed using the Error Analysis Theory from Richard (1974) to show how the second language learners produced the errors.

From the whole data, there are three texts that were translated using Venuti (2000) Translation Model and seventeen texts that were translated using Vinay and Darbelnet (1958) Translation Methods and Techniques/Procedures as it is shown in the following two tables.

Table 1 Translation using Venuti's (2000) Translation Model

\begin{tabular}{|c|c|c|}
\hline No & Translation & $\begin{array}{c}\text { Venuti's (2000) } \\
\text { Translation Model }\end{array}$ \\
\hline 1. & Aqua & $\begin{array}{l}\text { An original name of mineral water's trademark } \\
\text { produced by Danone, a French company producing } \\
\text { food and beverage. }\end{array}$ \\
\hline 2. & Jeans & $\begin{array}{l}\text { An original name of a type of fabric with various } \\
\text { trademarks. }\end{array}$ \\
\hline 3. & Toilet & $\begin{array}{l}\text { A place to urinate or defecate commonly known as } \\
\text { closet that has a broaden meaning into aplace to wash } \\
\text { our hands and face or a bathroom/a restroom. }\end{array}$ \\
\hline 4. & Aqua & $\begin{array}{l}\text { An original name of mineral water's trademark } \\
\text { produced by Danone, a French company } \\
\text { producing food and beverage. }\end{array}$ \\
\hline
\end{tabular}

Table 2 Translation using Vinay and Darbelnet (1958) Translation Methods and Techniques/Procedures

\begin{tabular}{|c|c|c|}
\hline \multirow{3}{*}{ No. } & \multirow{3}{*}{ Translation } & $\begin{array}{l}\text { Vinay and Darbelnet (1958) Translation } \\
\text { Methods and Techniques/Procedures }\end{array}$ \\
\hline & & Direct Method \\
\hline & & Borrowing Technique/Procedure \\
\hline 1. & Aqua & Borrowed from French (a trademark) \\
\hline 2. & Jeans & Borrowed from American (a type of fabric) \\
\hline \multirow[t]{2}{*}{3.} & Toilet & $\begin{array}{l}\text { Borrowed from English (a place to urinate or } \\
\text { defecate/a bathroom/restroom) }\end{array}$ \\
\hline & & Calque Technique/Procedure \\
\hline 4. & $\begin{array}{l}\text { Thus, technically you cannot } \\
\text { refer to gelato as ice cream } \\
\text { in the united states as it is } \\
\text { typically lower in butterfat. }\end{array}$ & $\begin{array}{l}\text { Jadi, secara teknis anda tidak dapat } \\
\text { menyamakan gelato seperti es krim di Amerika } \\
\text { Serikat karena ini (gelato) jenis (es krim) } \\
\text { yang rendah lemak. } \\
\text { It should be 'Gelato is different from American } \\
\text { ice cream as it is low-fat'. }\end{array}$ \\
\hline
\end{tabular}




\begin{tabular}{|c|c|c|}
\hline & & Literal Technique/Procedure \\
\hline 5. & $\begin{array}{l}\text { God and CCTV are always } \\
\text { watching. Act like your } \\
\text { mother saw you including } \\
\text { when you just sat down } \\
\text { and didn't order anything } \\
\text { moreover carrying food } \\
\text { from outside }\end{array}$ & $\begin{array}{l}\text { Tuhan dan CCTV selalu mengawasi (mu). } \\
\text { Bersikaplah seolah ibumu mengawasimu } \\
\text { termasuk ketika kau hanya duduk saja tanpa } \\
\text { memesan apapun apalagi membawa makanan } \\
\text { dari luar. }\end{array}$ \\
\hline 6. & $\begin{array}{l}\text { Education is the passport to } \\
\text { the future for tomorrow } \\
\text { belongs to those who } \\
\text { prepare for today. }\end{array}$ & $\begin{array}{l}\text { Pendidikan adalah kunci masa depan } \\
\text { masa deparena } \\
\text { mempersiapkannya sejak dini. }\end{array}$ \\
\hline 7. & No food or drink in this area & Dilarang makan dan minum di (area) ini. \\
\hline 8. & So sweet as ice cream & $\begin{array}{l}\text { Semanis es krim. } \\
\text { It should be 'as sweet as ice cream' or 'so sweet } \\
\text { like ice cream'. }\end{array}$ \\
\hline 9. & $\begin{array}{l}\text { You recognize bird from } \\
\text { their singing. } \\
\text { You *do people from their } \\
\text { talks. }\end{array}$ & $\begin{array}{l}\text { Burung dikenal dari nyanyiannya. } \\
\text { Manusia dikenal lewat kata-katanya. } \\
\text { It should be 'birds were known from its sound' } \\
\text { and 'people were known from their words.' }\end{array}$ \\
\hline 10. & Come again. We are closed. & $\begin{array}{l}\text { Datang lagi. Kami sudah tutup. } \\
\text { It should be only 'closed'. }\end{array}$ \\
\hline 11. & $\begin{array}{l}\text { Planting a tree *hung } \\
\text { thousand of hope. }\end{array}$ & $\begin{array}{l}\text { Menanam satu pohon menggantungkan seribu } \\
\text { harapan. } \\
\text { It should be 'planting one tree gives thousands } \\
\text { of hope'. }\end{array}$ \\
\hline & & Oblique Method \\
\hline & & Transposition Technique/Procedure \\
\hline 12. & $\begin{array}{l}\text { Skip the straw, save our pal. } \\
\text { (with a picture of } \\
\text { no straw movement symbol } \\
\text { and } \\
\text { two pictures of turtle } \\
\text { coming from Nemo } \\
\text { animation movie) }\end{array}$ & $\begin{array}{l}\text { Hindari menggunakan sedotan plastik untuk } \\
\text { menyelamatkan (penyu) sahabat kita. } \\
\text { Turtle is used as representation of animal as it } \\
\text { is a part of the ecosystem which was disturbed } \\
\text { by the plastic straw. }\end{array}$ \\
\hline & & Procedure \\
\hline 13. & Tobaco-free campus & $\begin{array}{l}\text { Kawasan bebas asap rokok. } \\
\text { Instead of translating 'kawasan bebas } \\
\text { asap rokok' into 'free-smoke area', the text } \\
\text { is translated into 'tobacco free campus' referring } \\
\text { to a campus that is free from tobacco (cigarette) } \\
\text { use along with all of its chemical content. }\end{array}$ \\
\hline & & $\begin{array}{l}\begin{array}{l}\text { Equivalence/Reformulation } \\
\text { Procedure }\end{array} \\
\text { Technique / }\end{array}$ \\
\hline 14. & Let's *bite it before *melt. & $\begin{array}{l}\text { Cicipi sebelum meleleh. } \\
\text { It should be 'taste it before melting' or 'taste it } \\
\text { before it melts' as ice cream should be tasted, } \\
\text { not biten. }\end{array}$ \\
\hline 15. & Fire Door & $\begin{array}{l}\text { Pintu darurat. } \\
\text { It should be'emergency door' although it is used } \\
\text { as an emergency exit for accident like a fire. }\end{array}$ \\
\hline & Bathroom tissue & $\begin{array}{l}\text { Tisu gulung. } \\
\text { It should be 'rolled tissue' although rolled } \\
\text { tissue is -indeed- commonly used in bathroom. }\end{array}$ \\
\hline
\end{tabular}




\begin{tabular}{lll}
\hline & & Adaptation Technique/Procedure \\
\hline 17. & $\begin{array}{l}\text { Parking } \\
\text { (with a picture of someone } \\
\text { sitting on a wheelchair) }\end{array}$ & $\begin{array}{l}\text { A particular parking lot for disabled. } \\
\text { person'. }\end{array}$ \\
\hline
\end{tabular}

Related to the Types of Error produced by second language learners (Dulay, 1982) and James (1998), there are fourteen texts containing five types of errors as follows.

Table 3 Types of Error produced by second/foreign language learners Dulay (1982) and James (1998)

\begin{tabular}{|c|c|c|}
\hline \multirow[t]{2}{*}{ No. } & \multirow[t]{2}{*}{ Translation } & \multirow{2}{*}{$\begin{array}{l}\text { Types of Error } \\
\text { Dulay (1982) and James (1998) } \\
\text { Omission }\end{array}$} \\
\hline & & \\
\hline \multirow[t]{2}{*}{1.} & *Temper glass. & $\begin{array}{l}\text { Omission of -ed2 Verb Inflection. } \\
\text { It should be 'tempered glass' meaning a tool } \\
\text { to cover cellphone's screen, not 'temper } \\
\text { glass' meaning a glass with bad temper. }\end{array}$ \\
\hline & & Addition \\
\hline 2. & *Breaked the limit. & $\begin{array}{l}\text { Addition of -ed } 2 \text { to the Verb Inflection } \\
\text { It should be 'break the limit' meaning go } \\
\text { beyond the normal way. }\end{array}$ \\
\hline 3. & Have you been *glowed. & $\begin{array}{l}\text { Addition of -ed } 2 \text { to the Verb Inflection } \\
\text { It should be 'have your car been washed / } \\
\text { shiny / glowing' meaning 'have your wash } \\
\text { your car that make it shiny /glowing'. }\end{array}$ \\
\hline 4. & Printing *packaging & $\begin{array}{l}\text { Addition of-ing Verb Inflection } \\
\text { It should be 'printing package'. }\end{array}$ \\
\hline 5. & *We're present. & $\begin{array}{l}\text { Addition of Auxiliary Verb 'be' } \\
\text { It should be 'we present something, }\end{array}$ \\
\hline \multirow[t]{2}{*}{6.} & We are *in here. & $\begin{array}{l}\text { Addition of Preposition 'in' } \\
\text { It should be 'we are here'. }\end{array}$ \\
\hline & & Misformation \\
\hline 7. & *Rolles es krim. & \multirow{3}{*}{$\begin{array}{l}\text { Mis-formation on adding Third Person } \\
\text { Singular Marker -es on Singular Subject. } \\
\text { It should be 'rolled', 'congratultion', and } \\
\text { 'reach'. }\end{array}$} \\
\hline 8. & $\begin{array}{l}* \text { Congratulations run worship } \\
\text { prayer }\end{array}$ & \\
\hline 9. & $\begin{array}{l}\text { *Reachs your aspiration is sky- } \\
\text { high }\end{array}$ & \\
\hline $10 .$. & $\begin{array}{l}\text { One stop *out of home media } \\
\text { company. }\end{array}$ & $\begin{array}{l}\text { Mis-formation on forming the Negation of } \\
\text { 'home media company' into 'out of home } \\
\text { media company'. } \\
\text { It should be 'one stop outdoor media } \\
\text { company.' }\end{array}$ \\
\hline 12. & $\begin{array}{l}\text { Stop *imagine, make } \\
\text { *a reality. }\end{array}$ & $\begin{array}{l}\text { Misformation of forming the Verb } \\
\text { 'imagining' -accompanying another Verb } \\
\text { 'stop'- and misformation of forming } \\
\text { Adjective 'real'. } \\
\text { It should be 'stop imagining, make it real.' }\end{array}$ \\
\hline & & Misordering \\
\hline 12. & Let's go green for *earth clean. & $\begin{array}{l}\text { Misordering the Noun Phrase 'earth clean'. } \\
\text { It should be 'for a clean earth'. }\end{array}$ \\
\hline 13. & Be *best your choice. & $\begin{array}{l}\text { Misordering the Adjective and the } \\
\text { Possessive. } \\
\text { It should be 'be your best choice.' }\end{array}$ \\
\hline
\end{tabular}


14. *Success key. Misordering the Noun Phrase.

It should be 'key success.'

In addition to the five types of error from Dulay (1982) and James (1998), due to the low English competence, twenty two texts were translated with lack of punctuation, typo, wrong form, and absurd meaning.

Table 4 Error caused by lack of punctuation, typo, wrong form, and absurd meaning

\begin{tabular}{|c|c|c|}
\hline No. & Translation & $\begin{array}{c}\text { Lack of Punctuation, Typo, } \\
\text { Wrong Form, and Absurd Meaning } \\
\text { Lack of Punctuation }\end{array}$ \\
\hline 1. & *Dont miss it. & $\begin{array}{l}\text { Lack of punctuation on the words 'dont' } \\
\text { to show Negation. } \\
\text { It should be 'don't'. }\end{array}$ \\
\hline \multirow[t]{3}{*}{2.} & *Levis and *Yulia Colection & $\begin{array}{l}\text { Lack of punctuation on the words 'Levis' } \\
\text { to show Possesive Marker. } \\
\text { It should be 'Levi's' and 'Yulia's } \\
\text { Collection'. }\end{array}$ \\
\hline & & Typo \\
\hline & & Lack of letter \\
\hline 3. & *Welcom turist, we spik inglish & It should be 'welcome tourist'. \\
\hline 4. & *Tubless & It should be 'tubeless'. \\
\hline 5. & *Expres & It should be 'express'. \\
\hline 6. & Bag Shop \& *Assesories & It should be 'accessoriess'. \\
\hline 7. & *Buterfly Success Key & It should be 'butterfly'. \\
\hline 8. & *Poket & It should be 'pocket'. \\
\hline \multirow[t]{2}{*}{9.} & Yulia *Colection & It should be 'collection'. \\
\hline & & Additional letter \\
\hline 10. & *Outdoour \& Semi Indoor & It should be 'outdoor'. \\
\hline 11. & $\begin{array}{l}\text { The food and drugs adminitration } \\
\text { *definies ice cream asa frozen } \\
\text { product wit no less than } 10 \% \\
\text { butterfat. }\end{array}$ & It should be 'defines'. \\
\hline \multirow[t]{2}{*}{12.} & $\begin{array}{l}\text { *Congratulations run worship prayer } \\
\text { and Reachs your aspiration is sky- } \\
\text { high. }\end{array}$ & It should be 'congratulation' and 'reach' \\
\hline & & Wrong letter \\
\hline 13. & Service *Electronik & It should be 'electronic service'. \\
\hline 14. & $*$ Teknical / *Teknicall & It should be 'technical'. \\
\hline 15. & *Potho copy / *Foto Copy & It should be 'Photocopy'. \\
\hline \multirow[t]{2}{*}{16.} & Welcom turist, we *spik inglish. & $\begin{array}{l}\text { It should be 'speak English' (an error } \\
\text { caused by imitating the pronounciation of } \\
\text { the words). }\end{array}$ \\
\hline & & Absurd meaning \\
\hline 17. & Over hole. & $\begin{array}{l}\text { It should be 'overhaul' meaning a } \\
\text { thorough machine check, not 'over hole' } \\
\text { meaning *an over hole / a hole that is } \\
\text { over? }\end{array}$ \\
\hline 18. & *Congratulations run worship prayer & $\begin{array}{l}\text { Selamat menjalankan ibadah sholat. } \\
\text { It should not be translated (literally) as in } \\
\text { English there are no wishes for praying. } \\
\text { It can be changed into 'happy praying' as } \\
\text { 'congratulations run worship prayer' }\end{array}$ \\
\hline
\end{tabular}




\begin{tabular}{|c|c|c|}
\hline & & $\begin{array}{l}\text { means } * \text { we congratulate someone who run } \\
\text { on worshiping a prayer }\end{array}$ \\
\hline 19. & *Reachs your aspiration is sky-high. & $\begin{array}{l}\text { Capailah cita-citamu setinggi langit. } \\
\text { It should not be translated as in English } \\
\text { there are no proverb like this. } \\
\text { It can be changed into 'reach the star' as } \\
\text { 'Reachs your aspiration is sky-high' } \\
\text { means *someone should have a high } \\
\text { aspiration as high as the sky. }\end{array}$ \\
\hline 20. & *Entry please & $\begin{array}{l}\text { Mohon antri. } \\
\text { It should be translated into 'queue' } \\
\text { meaning 'antri' or 'queueing line' } \\
\text { meaning 'tempat mengantri', not 'entry' } \\
\text { which means 'to let something in'. }\end{array}$ \\
\hline 21. & Toy-let & $\begin{array}{l}\text { Toilet. } \\
\text { It should not be translated as the word } \\
\text { 'toilet' is listed in both English dictionary } \\
\text { and KBBI and'toy-let' means *a toy that } \\
\text { let something. }\end{array}$ \\
\hline 22. & $\begin{array}{l}\text { Planting a tree hung thousand of } \\
\text { hope. }\end{array}$ & $\begin{array}{l}\text { Menanam satu pohon menggantungkan } \\
\text { seribu harapan. } \\
\text { It should not be translated into 'hung' as } \\
\text { the word 'menggantungkan' in this } \\
\text { sentence does not mean 'to hung; but 'to } \\
\text { count on something'. } \\
\text { It shoud be translatedinto 'planting one } \\
\text { tree gives thousands of hope'. }\end{array}$ \\
\hline
\end{tabular}

Based on Richards (1974) types of error produced by second language learners, the errors in Table 1 to 4 can be grouped into three, namely interference, overgeneralization, and performance error which is compiled in the following table.

Table 5 Types of Error: Interference, Overgeneralized, Performance Error (Richards, 1974)

\begin{tabular}{|c|c|c|}
\hline No. & Translation & $\begin{array}{l}\text { Types of Error } \\
\text { Richards (1974) } \\
\text { Interference }\end{array}$ \\
\hline 1. & $\begin{array}{l}\text { Thus, technically you cannot } \\
\text { refer to gelato *as ice cream in } \\
\text { the united states *as it is } \\
\text { *typically lower in butterfat. }\end{array}$ & $\begin{array}{l}\text { The error is caused by the interference of the first } \\
\text { language structure that makes the translator } \\
\text { translate the text literally. }\end{array}$ \\
\hline 2. & $\begin{array}{l}\text { God and CCTV are always } \\
\text { watching. Act like your mother } \\
\text { saw you *including when you } \\
\text { just sat down and didn't order } \\
\text { anything *moreover carrying } \\
\text { food } \\
\text { from outside }\end{array}$ & $\begin{array}{l}\text { The error is caused by the interference of the first } \\
\text { language structure that makes the translator } \\
\text { translate the text literally. } \\
\text { It is also influences by the translator's culture } \\
\text { where a mother commonly watch her kids out } \\
\text { and there are particular (bad) restaurant's visitors } \\
\text { who are only sitting in the restaurant enjoying } \\
\text { the place without ordering any menu and even } \\
\text { carrying food and beverage from outside. }\end{array}$ \\
\hline 3. & $\begin{array}{l}\text { Education is the passport to } \\
\text { the future for tomorrow } \\
\text { belongs to those who * prepare }\end{array}$ & $\begin{array}{l}\text { The error is caused by the interference of the first } \\
\text { language structure that makes } \\
\text { the translator translate the text literally. }\end{array}$ \\
\hline
\end{tabular}




\begin{tabular}{|c|c|c|}
\hline & for today. & \multirow{3}{*}{$\begin{array}{l}\text { It is also caused by the translator's lack of } \\
\text { translation knowledge that proverb should not } \\
\text { always be translated literally. }\end{array}$} \\
\hline 4. & $\begin{array}{l}\text { You recognize bird from their } \\
\text { singing. } \\
\text { You *do people from their } \\
\text { talks. }\end{array}$ & \\
\hline 5. & $\begin{array}{l}\text { Planting a tree } * \text { hung thousand } \\
\text { of hope. }\end{array}$ & \\
\hline 6. & Come again. We are closed. & $\begin{array}{l}\text { The error is caused by the interference of the first } \\
\text { language structure that makes } \\
\text { the translator translate the text literally. } \\
\text { It also caused by the translator's culture where a } \\
\text { restaurant usually expect visitors to comeback } \\
\text { when they are open again after they were closed. }\end{array}$ \\
\hline 7. & $\begin{array}{l}\text { One stop *out of home media } \\
\text { company }\end{array}$ & $\begin{array}{l}\text { The error is caused by the interference of the first } \\
\text { language structure that makes the translator } \\
\text { translate the text literally by forming the } \\
\text { negation of 'at home' meaning 'di dalam rumah' } \\
\text { into 'out of home' meaning 'di luar rumah'. }\end{array}$ \\
\hline 8. & Stop *imagine, make *a reality. & $\begin{array}{l}\text { The error is caused by the interference of the first } \\
\text { language structure that makes the translator } \\
\text { translate the text literally by using the wrong } \\
\text { form of the word class as he/she does not } \\
\text { understand the different form of the word in } \\
\text { different word class. } \\
\text { He/she thinks that 'berhenti berkhayal' is } \\
\text { correctly translated into 'stop imagine' not 'stop } \\
\text { imagining' that means '*berhenti sedang } \\
\text { berhayal'. } \\
\text { He/she also thinks that 'realita' is correctly } \\
\text { translated into 'reality'. }\end{array}$ \\
\hline 9. & Let's go green for *earth clean & $\begin{array}{l}\text { The error is caused by the interference of the first } \\
\text { language structure that makes the translator } \\
\text { translate the text literally by forming the } \\
\text { wrong order of the Noun Phrase following the } \\
\text { first language structure of 'bumi bersih' into } \\
\text { 'earth clean'. }\end{array}$ \\
\hline 10. & Be *best your choice. & $\begin{array}{l}\text { The error is caused by the interference of the first } \\
\text { language structure that makes the translator } \\
\text { translate the text literally by forming the } \\
\text { wrong order of the Adjective and Possessive } \\
\text { following the first language structure of 'pilihan } \\
\text { terbaikmu' into 'best your choice'. }\end{array}$ \\
\hline 11. & We are $*$ in here. & $\begin{array}{l}\text { The error is caused by the interference of the first } \\
\text { language structure that makes the translator } \\
\text { translate the text literally } \\
\text { unnecessary Preposition 'in' to the Adverb of } \\
\text { Place following } \\
\text { the first language structure of 'di sini' into 'in } \\
\text { here'. }\end{array}$ \\
\hline 12. & *Temper glass. & $\begin{array}{l}\text { The error is caused by the interference of the first } \\
\text { language structure that makes the translator } \\
\text { translate the text by not adding the Past Tense } \\
\text { Marker (-ed) following the first language } \\
\text { structure that has no Past Tense Marker -ed. }\end{array}$ \\
\hline
\end{tabular}




\begin{tabular}{ll}
\hline 13. & *Dont miss it. \\
\hline 14. & *Levis and *Yulia Colection \\
& \\
& \\
\hline 15. & Yulia *Colection \\
\hline 16. & *Expres \\
\hline 17. & *Buterfly Success Key
\end{tabular}

The error is caused by the interference of the first language structure that makes the translator translate the text by omitting punctuation since there is no puctuation for short Negation and Possessive Marker in the first language structure. The error is caused by the interference of the first language structure that makes the translator translate the text by omitting letter since there is no double ' $l$ ' ' $s$ ' or ' $t$ ' letter in the first language structure.

\begin{tabular}{ll}
\hline 18. & $*$ Tubless \\
\hline 19. & $*$ Welcom turist, we spik inglish
\end{tabular}
The error is caused by the interference of the first language structure that makes the translator translate the text by omitting letter since there is no unsounded letter ' $e$ ' in the final position like tube and welcome.

\begin{tabular}{lll}
\hline 20. *Poket & The error is caused by the interference of the first \\
& language structure that makes the translator \\
translate the text by omitting unsounded letter 'c' \\
before'k' since there is no double consonants \\
'ck'.
\end{tabular}




\begin{tabular}{|c|c|c|}
\hline 28. & *Rolles es krim & \multirow{3}{*}{$\begin{array}{l}\text { The error occurs when the translator } \\
\text { overgeneralized the second language structure by } \\
\text { adding unnecessary form of the Third Person } \\
\text { Singular Marker (-s/-es ) to Singular Subject. }\end{array}$} \\
\hline 29 & $\begin{array}{l}\text { *Congratulations run worship } \\
\text { prayer }\end{array}$ & \\
\hline 30. & $\begin{array}{l}\text { *Reachs your aspiration is } \\
\text { sky-high }\end{array}$ & \\
\hline 31. & *We're present. & $\begin{array}{l}\text { The error occurs when the translator } \\
\text { overgeneralized the second language structure by } \\
\text { adding unnecessary form } \\
\text { the Auxiliary Verb (are). }\end{array}$ \\
\hline 32. & Buterfly *Success Key & $\begin{array}{l}\text { The error occurs when the translator } \\
\text { overgeneralized the second language structure by } \\
\text { putting the Noun after } \\
\text { the Adjective in a Noun Phrase. }\end{array}$ \\
\hline 33. & Bag Shop \& *Assesories & $\begin{array}{l}\text { The error occurs when the translator } \\
\text { overgeneralized the second language structure by } \\
\text { putting double's' letter 's' although the word } \\
\text { form is still incorrect. }\end{array}$ \\
\hline 34. & *Potho & $\begin{array}{l}\text { The error occurs when the translator } \\
\text { overgeneralized the second language structure by } \\
\text { using word that looks correct 'potho' resemble } \\
\text { 'potho' although } \\
\text { the word form is still incorrect. }\end{array}$ \\
\hline 35. & *Teknicall & $\begin{array}{l}\text { The error occurs when the translator } \\
\text { overgeneralized the second language structure by } \\
\text { using the word 'call' or giving double 'l' letter in } \\
\text { the final position. }\end{array}$ \\
\hline 36. & Outdoour \& Semi Indoor & The error is occurs when translator \\
\hline 33. & $\begin{array}{l}\text { The food and drugs } \\
\text { adminitration definies ice } \\
\text { cream asa frozen product with } \\
\text { no less than } 10 \% \text { butterfat. }\end{array}$ & $\begin{array}{l}\text { overgeneralized the pattern of the second } \\
\text { language by adding unecessary letter ' } i \text { ' } \\
\text { resembling the second language word form } \\
\text { although the word form is still incorrect. }\end{array}$ \\
\hline & & Performance Error \\
\hline 38. & Over hole. & The error occurs when the translator think that \\
\hline 39. & $\begin{array}{l}\text { *Congratulations run worship } \\
\text { prayer }\end{array}$ & $\begin{array}{l}\text { the correct form of each words he/she has } \\
\text { translated bear the same meaning with the }\end{array}$ \\
\hline 40. & $\begin{array}{l}\text { *Reachs your aspiration is } \\
\text { sky-high }\end{array}$ & \\
\hline 41. & Entry please & \\
\hline 42. & Toy-let & \\
\hline 43. & $\begin{array}{l}\text { Planting a tree hung thousand } \\
\text { of hope. }\end{array}$ & \\
\hline
\end{tabular}

\section{DISCUSSION}

Translation Model (Venuti, 2000) and Method and Technique/Procedure (Vinay and Darbelnet, 1958)

From the finding in Table 1, we can see that three texts were translated by applying Venuti (2000) Translation Model using the original word caused by different factors as follows.

1. 'Aqua' is a particular trademark of packaged mineral water produced by Danone, a French company producing food and beverage. It will be odd if it is translated as the referrent will be different from the original object. 
2. 'Jeans' is a particular fabric previously used by mining worker in America. It has no translation in English as it is a name/type of fabric.

3. 'Toilet' comes from an English word toilet which means the closet, an object that is used to urinate or defecate which is broaden in meaning into a place to wash our hands and face or a bathroom/a restroom. It can be translated into Water Closet or 'Kamar Mandi' but it is more common to use the word 'toilet' as it means a bathroom/restroom with toilet/closet inside.

Those three words were not translated since it might create misunderstanding if it is translated as it might refer to different object.

From the finding in Table 2, we can see that seventeen texts were translated by applying Vinay and Darbelnet (1958) Translation Methods and Techniques/Procedures caused by different factors below.

1. 'Aqua' is translated by using Direct Method with Borrowing Technique/Procedure by borrowing a particular trademark of packaged mineral water produced by a French company producing food and beverage called Danone, as it will refer to different object if it is translated.

2. 'Jeans' is translated by using Direct Method with Borrowing Technique/Procedure by borrowing a particular fabric name previously used by mining worker in America, as there is no translation in English for it.

3. 'Toilet' is translated by using Direct Method with Borrowing Technique/Procedure by borrowing an English word meaning an object that is used to urinate or defecate which is broaden in meaning into a place to wash our hands and face or a bathroom/ a restroom, as it has a more comprehensive meaning of a bathroom / restroom equipped with toilet inside.

4. 'Thus, technically you cannot refer to gelato as ice cream in the united states as it is typically lower in butterfat.' and 'God and CCTV are always watching. Act like your mother saw you including when you just sat down and didn't order anything moreover carrying food from outside.' were translated using Direct Method with Calque Technique/Procedure to follow the first language structure to deliver similar message and to let the second language learners understand the meaning.

5. 'Education is the passport to the future for tomorrow belongs to those who prepare for today', 'No food or drink in this area', 'So sweet *as ice cream', 'You recognize bird from their singing. You *do people from their talks.', 'Come again. We are closed.' and 'Planting a tree *hung thousand of hope.' were translated using Direct Method with Literal Technique/Procedure to follow the first language structure to deliver similar message and to avoid misuderstanding although it resulted in error and shift in form and meaning.

6. 'Skip the straw, save our pal' is translated using Oblique Method with Transposition Technique/Procedure to make a slight change of 'animal affected by plastic straw' into 'our pal' referring to the turtle to show that they are close to us as humankind so that we need to keep them safe as part of our ecosystem.

7. 'Tobacco-free campus' is translated using Oblique Method with Equivalence / Reformulation Technique/Procedure to modulate the phrase 'kawasan bebas asap rokok' into 'tobacco-free campus' to cover the whole area (of the particular campus) as an area free from tobacco and all of its harmful chemical content (cigar, cigarette, smoke).

8. 'Let's *bite it before *melt', ' Fire Door', and 'bathroom tissue' were translated using Oblique Method with Equivalence/Reformulation Technique/Procedure to express 
the text in different way such as 'tasting' for 'eating', 'emergency room' for 'fire exit' and 'bathroom tissue' for 'rolled tissue'.

9. 'Parking' is translated using Oblique Method with Adaptation Technique / Procedure to show that the parking area is specifically dedicated for car with disabled person inside who need extra space and time to get in and out from a car as it is shown by the picture of someone sitting on a wheelchair.

\section{Types of Error in Translation (Dulay, 1982 and James, 1998)}

From the finding in Table 3, we can see that fourteen texts containing five types of errors (Dulay, 1982 and James, 1998) caused by the following different factors.

1. '*Temper glass' contains Omission as it is translated by omitting -ed2 of the Verb 'tempered' as a result of the idea that -ed is Past Tense Marker so that it is not suitable to use as it means '*temper in the past'.

2. '*Breaked the limit' and 'Have you been *glowed' contain Addition as they were translated by adding -ed2 of the Verb 'breake' and 'glow' as a result of the idea that -ed is Past Tense Marker so that it is suitable to be added into the Verb 'break' that should be changed into 'broke' to show the Past Tense as it is an irregular Verb and the Verb 'glow' that should be changed into 'glowing' to show the Adjective form.

3. 'Printing *packaging is translated by adding -ing Verb Inflection to the word 'package' as a result of the idea that adding -ing to the word 'package' bear the same result as adding -ing to the word 'printing' creating the Noun.

4. '*We're present' contain Addition as they were translated by adding unecessary Auxiliary Verb 'are' after the Noun 'we' as a result of the idea of Subject-Verb Agreement where 'we' should be followed by the Auxiliary Verb 'are'.

5. '*Rolles es krim', '*Congratulations run worship prayer' and '*Reachs your aspiration is sky-high' Misformation as it is translated by adding Third Person Singular Marker es on the word 'roll' to translate 'gulung' as a result of the idea of Subject-Verb Agreement where Third Person Singular should be added with -s/-es.

6. 'One stop *out of home media company' contains Misformation as it is translated by forming 'out of home' as a negation for 'at home' as a result of the idea that the antonym of 'at home' meaning 'inside the house' is 'out of home' meaning 'outside the house'.

7. 'Stop *imagine, make *a reality' contains Misformation as it is translated by using the Verb 'imagine' for 'berkhayal' and The Noun 'reality' for 'kenyataan' or 'realita' as a result of the idea that 'imagining' is incorrect as it means 'sedang berkhayal' and 'make it real' is incorrect as it meand 'membuat nyata'.

8. 'Let's go green for *earth clean' contains Misordering as it is translated by creating incorrect order of the Noun Phrase 'untuk bumi yang bersih' into 'for earth clean' as a result of the first language structure influence placing Verb after Noun.

9. 'Be *best your choice.' contains Misordering as it is translated by creating incorrect order of the Adjective and Possessive as a result of the incorrect combination of 'be the best' and 'your choice'.

10. '*Success key' contains Misordering as it is translated by creating incorrect order of the Adjective and Noun form as a result of the second language structure influence of translating 'kunci kesuksesan' into 'success key'.

11. 'We are *in here' contains Misordering as it is translated by creating incorrect order of the Preposition of the Adverb of Place as a result of the first language structure influence of translating 'di sini' into 'in here'. 
In addition to five types of errors (Dulay, 1982 and James, 1998), based on Table 4, there are also twenty two texts containing error such as Lack of Punctuation, Typo, Wrong Form, and Absurd Meaning caused by different factors.

1. '*Dont miss it', '*Levis', and '*Yulia Colection' contain error as they were translated by omitting punctuation on the Negation of 'dont' and the Possessive Marker of 'Levis' and 'Yulia's' as a result of the first language structure influence that has no pucntuation for Negation and Possessive.

2. '*Welcom turist', '*Expres', '*Assesories', '*Tubless', '*Buterfly', *Poket', and '*Colection' contain error as they were translated by omitting particular letter as a result of the first language structure influence that has no double consonants ' 1 ', 's' and ' $t$ ', double consonant 'ck', unsounded final vowel 'e' and dipthong 'ou'.

3. '*Outdoour' and '*definies' contain error as they were translated by adding particular letter as a result of the low competence of English spelling and writing.

4. '*Congratulations' and '*reachs' contain error as they were translated by adding $-\mathrm{s}$ showing Third Person Singular Marker resulted from the second language structure influence of Subject-Verb Agreement where the Singular Subject should be added with - s.

5. '*Poket', ‘*Electronik', ‘*Teknical', ‘*Teknicall' and '*Foto copy' contain error as they were translated by putting wrong letter to the word as a result of the first language structure influence of the use of ' $k$ ' letters to replace ' $c$ ' letter on the word 'electronic', ' $\mathrm{k}$ ' letter to replace 'ch' letters on the word 'teknical' and 'teknicall' and ' $\mathrm{f}$ ' letters to replace 'ph' letters on the word 'photo'.

6. '*Teknicall' and '*Potho copy' contain error as they were translated by putting wrong letter to the word as a result of the second language structure influence of the use of the word 'call' as part of the word 'teknicall' and misforming the word 'photo' by putting the letter ' $h$ 'to the second syllabe instead of the first syllable.

7. '*spik Inglish' contains error as a result of the first language structure influence as it is translated by writing the pronounciation of the original word in English.

8. '*Over hole', '*Congratulations run worship prayer', '*Reachs your aspiration is sky-high, '*Entry please', '*Toy-let', and '*Planting a tree hung thousand of hope' contains error as they were translated literaly by translating word-for-word leading to incorrect form and meaning resulting form and meaning shift of the whole text even though each word has correct meaning.

From the finding in Table 5, forty two errors are grouped into Interference, Overgeneralized and Performance Error (Richards, 1974) caused by different factors.

\section{Interference}

1. 'Thus, technically you cannot refer to gelato as ice cream in the united states as it is typically lower in butterfat' contains error as an interference of the first language structure as it is translated literaly word-for-word leading to incorrect form and meaning resulting form and meaning shift of the whole text although each word has correct meaning.

2. 'Education is the passport to the future for tomorrow belongs to those who prepare for today', 'You recognize bird from their singing. You do people from their talks', and 'Planting a tree hung thousand of hope' contain error as an interference of the first language structure as it is translated literaly word-for-word leading to incorrect form and meaning and also resulted in form and meaning shift of 
the whole text although each word has correct meaning. It is also caused by the translator's lack of knowledge that proverb should not be translated literally.

3. 'God and CCTV are always watching. Act like your mother saw you including when you just sat down and didn't order anything moreover carrying food from outside' and 'Come again. We are closed.' contain error as an interference of the first language structure as it is translated literaly word-for-word leading to incorrect form and meaning and also resulted in form and meaning shift of the whole text although each word has correct meaning. It is also caused by the translator's cultural background where a mother commonly watch her kids out and there are particular (bad) restaurant's visitors who are only sitting in the restaurant enjoying the place without ordering any menus and even carrying food and beverage from outside (first error) and a restaurant usually expect visitors to comeback when they are open again after they were closed (second error).

4. 'One stop *out of home media company' contains error as an interference of the first language structure as it is translated literally by forming the negation of 'at home' meaning 'di dalam rumah' into 'out of home' meaning 'di luar rumah'.

5. 'Stop *imagine, make *a reality' contains error as an interference of the first language structure as it is translated by using the wrong word class as he/she thinks that 'berhenti berkhayal' is correctly translated into 'stop imagine' meaning '*berhenti sedang berhayal'. He/she also thinks that 'realita' is correctly translated into 'reality' so that 'make a reality' means '*membuat kenyataan'.

6. 'Let's go green for *earth clean' and 'Be *best your choice' contains error as an interference of the first language structure as it is translated literally by forming the wrong order of the Noun Phrase of 'bumi bersih' into 'earth clean', the wrong order of the Adjective and Possessive Marker of 'pilihan terbaikmu' into 'best your choice', and adding unnecessary Preposition 'in' to the Adverb of Place 'here'.

7. 'We are *in here' contains error as an interference of the first language structure as it is translated literaly by adding unncessary Preposition 'in' to the Adverb of Place 'here'.

8. '*Temper glass' contains error as an interference of the first language structure as it is translated by omitting the Past Tense Marker (-ed) as he/she thinks that 'tempered glass' it is incorrect translation meaning 'glass with past temper'.

9. '*Dont miss it.', '*Levis' and '*Yulia Colection' contains error as an interference of the first language structure as it is translated by omitting punctuation since there is no puctuation for short Negation and Possessive Marker in the first language structure.

10. 'Yulia *Colection', '*expres', and '*buterfly' contains error as an interference of the first language structure as it is translated by omitting double consonants ' 1 ', 's' and ' $t$ ' since it is not found on the first language structure.

11. '*Tubless' and '*Welcom' contains error as an interference of the first language structure as it is translated by omitting unsounded ' $\mathrm{e}$ ' letter in the final position of 'tube' and 'welcome' since it is not found on the first language structure.

12. '*Poket', '*electronik', '*teknical', '*teknicall', '*foto copy','*buterfly', and '*colection' contains error as an interference of the first language structure as it is translated by omitting the letter ' $c$ ' before the letter ' $\mathrm{k}$ ' on the word 'poket', replacing the letter ' $c$ ' in the final position of the word 'electronik', replacing double consonants 'ch' with the letter ' $\mathrm{k}$ ' on the word 'teknical' or 'teknicall', replacing the double consonants 'ph' on the word 'photo' with the letter ' $\mathrm{f}$ ', and omitting the letter ' $\mathrm{t}$ ' and ' $\mathrm{l}$ ' to form double consonant on the word 'buterfly' and 'colection' as those errors are common spelling in the first language structure. 


\section{Overgeneralized}

13. '*Teknicall' and '*potho copy' contains error as an interference of the second language structure as it is translated by adding the word 'call' as a second syllable on the word 'teknicall' and adding the letter ' $h$ ' to form the double consonant on the word 'potho' even though the final form is still incorrect.

14. '*Assesories' contains error as an interference of the second language structure as it is translated by replacing the first double consonant 'cc' with the double consonant 'ss' and omitting the letter ' $s$ ' to form the second double consonant 'ss' on the word 'assessories' as a misformation type of error.

15. '*Breaked' and '*glowed' contains error as an interference of the second language structure as it is translated by adding wrong form of the Past Tense Marker (-ed) referring to something that has already been done.

16. '*We're present' contains error as an interference of the second language structure as it is translated by adding unnecessary form the Auxiliary Verb (are) commonly added after the Subject 'we'.

17. '*Success key' contains error as an interference of the second language structure as it is translated by putting the Noun after the Adjective in a Noun Phrase as a misordering type of error.

18. '*Outdoour' and '*definies' contains error as an interference of the second language structure as it is translated by adding unnecessary letter ' $u$ ' and ' $i$ ' on the word 'outdoour' and 'definies'.

\section{Performance Error}

19. '*Planting a tree hung thousand of hope, '*Congratulations run worship prayer', '*Reachs your aspiration is sky-high', '*Over hole', 'Entry please' and 'Toy-let' contains error as translator think that the correct form of the translated words deliver the same meaning with the original language although it is not.

\section{CONCLUSION}

Error is commonly produced by a speaker mastering a second/foreign language as their first language may influence their second/foreign language production. However, those errors can be limited or avoided by giving highlight on particular types of errors commonly occur in the translation. The result of this research can be developed into a guidance of proper translation for public facilities as it is displayed in public.

\section{REFERENCES}

Dulay, Heidi., 2002. Marina Burt and Stephen Krashen. 1982. Language Two. London: Oxford University Press.

James, Carl, 1998. Errors in Language Learning and Use. Singapore: Singapore: Wesley Longman Singapore Ltd.

Richard, Jack C. 1974. Error Analysis, Perspective in Second Language Acquisition, London: Longman Group Ltd.

Catford, J.C. 1965. A Linguistics Theory of Translation. Oxford: Oxford University Press. 
Nida \& Taber. 1969. Theory and Practices of Translation. Leiden: E.J Brill

Sudaryanto. 1993. Metode dan Aneka Teknik Analisis Bahasa. (Pengantar Penelitian Wacana Kebudayaan secara Linguistik). Yogyakarta: Duta Wacana

Venuti, Lawrence. 2000. The Translation Studies Reader. London: Routledge.

Vinay, J.P.and Darbelnet, J. (1958/2000). A Methodology for Translation. [An excerpt from Comparative Stylistics of French and English: A Methodology for Translation, trans. and eds. J. C. Sager \& M.J. Hamel, Amsterdam: John Benjamins, 1995, first published in 1958 as Stylistique comparée du français et de l'anglais. Méthode de traduction] In L. Venuti (Ed.), The Translation Studies Reader(pp. 84-93). London: Routledge 


\section{APPENDIX}

\section{Pictures of Translation on Public Facilities around Semarang City}

\begin{tabular}{|c|c|c|c|}
\hline No. & Translation & No. & Translation \\
\hline 1 & 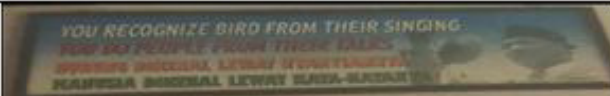 & 26. & $\begin{array}{l}\text { WEICOM TUURISI } \\
\text { WE SIPIE INGHISIH }\end{array}$ \\
\hline 2. & 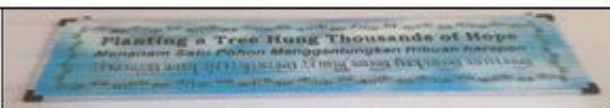 & 27. & \\
\hline 3. & & 28. & ( \\
\hline 4. & 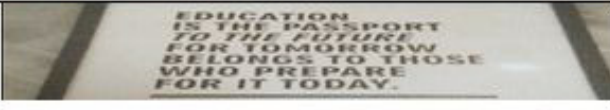 & 29. & m \\
\hline 5. & 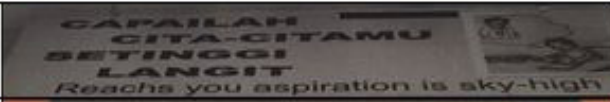 & 30. & 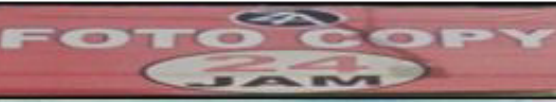 \\
\hline 6. & & 31. & PIIC \\
\hline 7. & 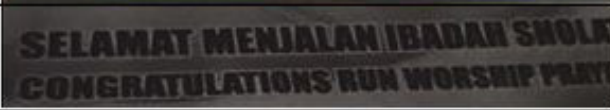 & 32. & \\
\hline 8. & 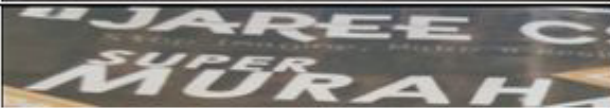 & 33. & $+1-0$ \\
\hline 9. & Five & 34. & 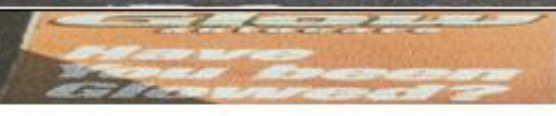 \\
\hline 10. & 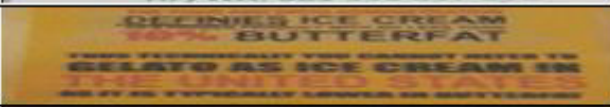 & 35. & 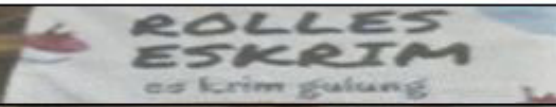 \\
\hline
\end{tabular}




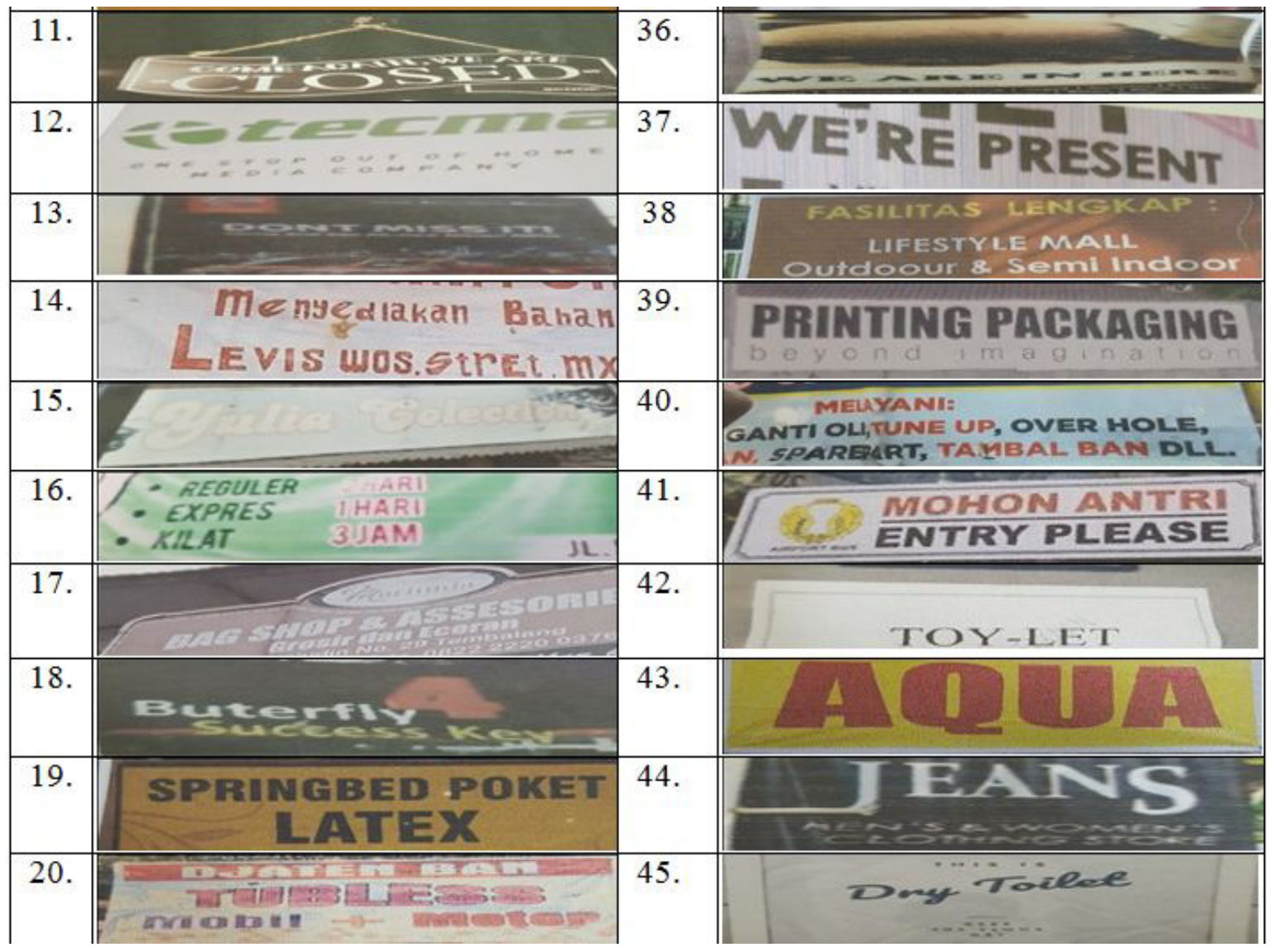

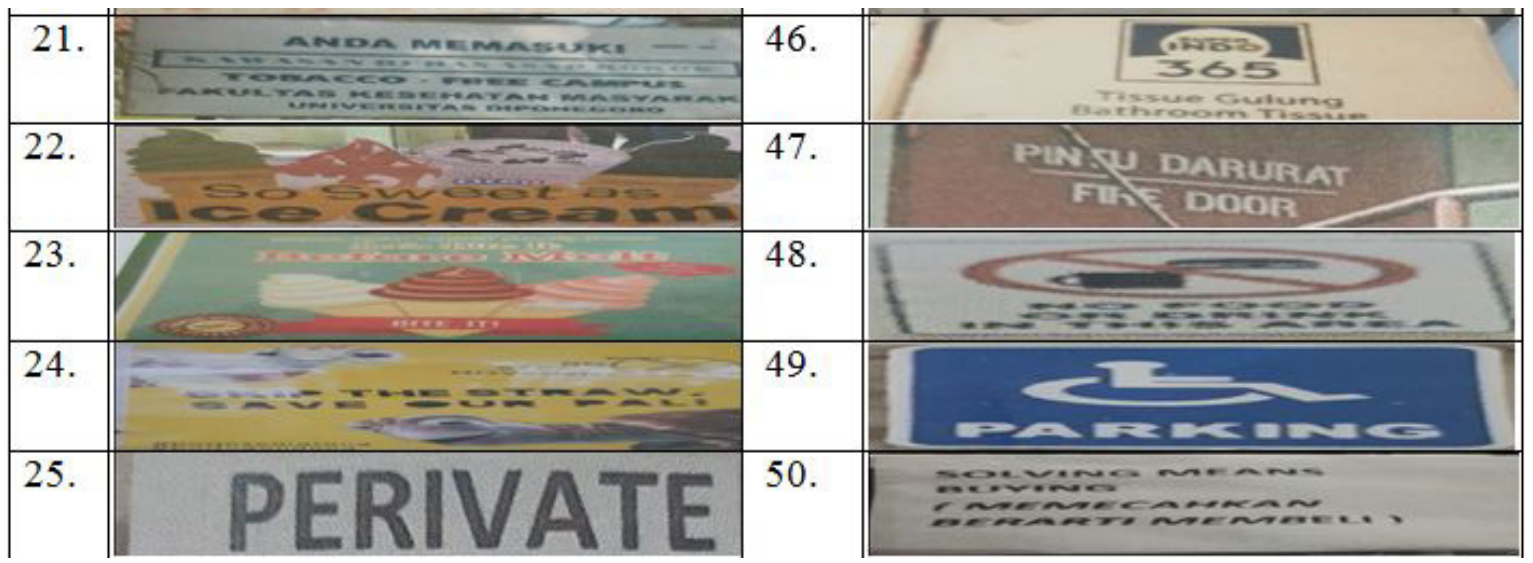

